\title{
Nexhip Mërkuri
}

Universiteti “Ismail Qemali”, Vlorë

\section{Patronia shqiptare në evoluimet ballkanike dhe europiane}

\begin{abstract}
Autori pasqyron evoluimin e patronimisë. Zhvillimet, pritjet e patronimisë jepen pas materialit të mbledhur në arkivat e mundshme nga ekspeditat e realizuar në disa rajone.

Ka hulumtuar si një dukuri gjuhësore ballkanike edhe për Ilirinë, Arbërinë, gjuhën shqipe.

Gjatë Mesjetës identifikimi i shqiptarëve bëhet nëpërmjet një emri vetjak, patronimit që mund të jetë $i$ babait ose i gjyshit, duke shtuar dhe vendlindjen edhe emrin e fshatit apo të krahinës për të treguar prejardhjen. Mëshohet më tepër tek hulumtimi i evoluimit të patronimisë në 100 vjetët e fundit. Krahasohet gjendja e trashëguar nga sundimi turk dhe jepen prirjet që kultivoi Komisia Letrare e Shkodrës (1 shtator 1916), e cila ishte bashkëpunim me gjuhëtarë të universiteteve europiane. Kërkimet $i$ autorit janë pjesë e studimit të gjerë në fushën e onomastikës.
\end{abstract}

Fjalët kyç: patronimi, Arbëri, komisi letrare, prirje, ekspeditë, arkiva, identifikim i shqiptarëve.

Kërkimet në fushën e onomastikes nga gjuhëtarë me përvojë kanë sjellë për brezat variante të mundshme të formimit të emrit të familjes dhe shkrimit me kujdes. Këto hulumtime në shekuj për karakterin marrëveshjesor krahinor, kombëtar, ballkanas, apo dukuri globale për emrin e familjes vijojnë edhe sot. Arsyet etnopsikologjike, koha e gjatë e politikës gjuhësore më shumë se një shekull shoqërohen edhe me ndryshime të tjera që paraqesin patronimet e vjetra, evoluimi, tek ato emra familjesh që kemi në përdorim.

Fillimi i hershëm si veçim i patronimisë që edhe gjuhëtarët modistë të Mesjetës i ruajtën të paprekura të gjitha hollësitë e Gramatikës së Latinishtes së Prishiamit dhe Donatit si pasqyrim i saktë i strukturës së realitetit dhe aftësive të mendjes së njeriut si p.sh.: ndarja e emrave të përveçëm në praenomina "përemra' dhe cognomina"mbiemra' dhe agnomina "nofka'; 
të gjitha këto kategori të lidhura ngushtësisht me onomastikën e latinishtes (Robins 2007:129).

Po fqinjët e latinëve, karakterin marrëveshjesor të patronimit shqiptar si ka evoluar në hapësirën ballkanike dhe atë europiane?

Mëshohet hulumtimi si një dukuri gjuhësore ballkanike edhe për Ilirinë, Arbërinë, gjuhën shqipe. Evolucioni i patronimeve ka ardhur duke u plotësuar, pavarësisht politikave gjuhësore. Zhvillimet, pritjet e patronimisë jepen pas materialit të mbledhur në arkivat e mundshme nga ekspeditat e realizuar në disa rajone. Mëshohet edhe te karakteri marrëveshjesor krahinor për zgjedhjen e kompleksit gjuhësor, pra si funksion evolues emër familje në Toskërishten Veriore e më gjerë. Çfarë ka renditur si prirje tek emrat e familjeve procesi i evoluimit?

\section{Politikat gjuhësore dhe emri i familjes}

Periudha e Mesjetës tregon për thyerje të sistemit dhe emrave të familjeve me pushtimin osman të vendit. Pushtuesi aziatik, bashkë me fenë solli edhe antroponiminë, patroniminë islame si pjesë e politikës së tij gjuhësore. Kjo politikë gjuhësore nisi të zëvendësojë emrat e arbërve, të shqiptarëve që deri në këtë kohë kishin qenë vetëm të krishterë.

Gjatë Mesjetës identifikimi i shqiptarëve bëhet nëpërmjet një emri vetjak, patronimit që mund të jetë i babait ose i gjyshit, duke shtuar dhe vendlindjen edhe emrin e fshatit apo të krahinës për të treguar prejardhjen.

Përpjekja e parë serioze për të analizuar edhe emrat e familjes është ajo e Milan Shuflait në veprën e tij "Historia e Shqipërisë së Veriut". Aty Shuflai sheh bashkëjetesën e dy emrave te shqiptarët: të emrit të krishterë dhe të emrit të vendbanimit, i cili shpesh është edhe emri i fisit. Ai përcakton një lidhje të pandërprerë midis emrave shqiptarë dhe lashtësisë ilire, megjithëse është i mendimit se parimi i emrave indoevropianë sipas të cilit janë formuar fjalët e përbëra një parim që mund të vërehet te ilirët duhet të jetë humbur edhe te shqiptarët ashtu si edhe tek malësorët e tjerë arianë (frigasit, armenët).

Shuflai ka dhënë edhe klasifikim e parë të përmbledhur të emrave mesjetarë shqiptarë që kanë prejardhjen e tyre nga ofiqet e nga profesionet. Nga kjo analizë Shuflai arrin në përfundimin se shqiptarët kishin arritur në Mesjetë një shkallë qytetërimi të lartë (Kostallari 2017:181).

Hulumtuam si dokument librin e historianit përmetar Stiljan Adhami "Përmeti dhe përmetarët në faqet e historisë nga lashtësia deri 1939" (Adhami 2001:1-829). Autori i librit nëpërmjet një pune voluminoze hulumtuese mbi dokumentet arkivore autentike ka shfrytëzuar një bibliografi të gjerë (për të mos thënë pothuajse gjithçka më thelbësore të shkruar aty - këtu për Përmetin dhe përmetarët) shtypin, para dhe pas Çlirimit si edhe dokumente të vjela për 
vite më radhë, një sërë kujtimesh e tregimesh gojore, përmetarë të moshuar, veprimtarë apo dëshmitarë okularë e njohës të ngjarjeve e figurave të shquara si edhe udhëpërshkrimet e të huajve të shekujve XVII-XX.

Në këto dokumente historike shkoqitet se procesi i stabilizimit të emrit, emrit të familjes edhe në trevën e Përmetit, i cili ka qenë i gjatë. Faktorët që kanë ndikuar janë po ata që kanë përcaktuar për gjithë emrat dhe emrave të familjeve shqiptare.

Duke paraqitur në kapitullin "Gjurmë në lashtësi” me nënndarjet: lashtësi prehistorike në Dedejan, Parauejtë - banorët e lashtë të luginës së sipërme të Vjosës, qyteza e lashtë e Limarit, kalaja e Këlcyrës ose e Trebeshinës, qyteza e Kuqarit, kultura materiale e varrezave në Piskovë-Rapckë, Grabovë, Guri i Qytetit, legjendë në histori, kalaja e Bolëngës, Tri kala në zona periferike, qendra dhe gjurmë të tjera të hershme, mosha e qyteteve Përmet-Këlcyrë (f.15-59). Përmendet mbreti Oroidi i fisit ilir të Parauejve, Pirro, Efialti-bari tradhtar, Gjergji - themelues i qytetit, vajza -Distra, Premti etj. Paraqitet një dukuri gjuhësore ballkanike edhe për Ilirinë duke paraqitur vetëm një emër si: Aleksandër, Hektor, Platon etj.

Në kreun "Aspekte nga historia mesjetare" tek nënndarjet: kryengritje kundër sundimtarëve bizantinë, regjistrimet e para osmane, burime historike me vlerë, tipare të feudalizmit turko-osman.

Gjenden në këto faqe, mënyrë identifikimi nëpërmjet emrit të parë të prirë nga një titull a gradë: Haxhi Mihal Daliani, Sinan bej Frashëri, Hasan bej Këlcyra, Mehmet Pashë Frashëlliu, Qedik Ahmet Pasha (komandant sipas Çelebiut) Mirahor Iljiaz beu, Husen Pasha, Murat Osman Beu nga Kurtesi etj.

Titujt dhe gradat e marra në administratë $u$ përkasin nëpunësve të ndryshëm, të cilat gjejnë një përdorim të gjerë në fillim bashkëngjitur pas emrave.

Po në këto dokumente të nxjerra nga arkivat e kohës shfaqet edhe formula dominuese trigjymtyrëshe, gjymtyra e tretë siç ka përzgjedhur T. Osmani, që shënojnë origjinën e vendbanimit, i cili është emër: fshati, qyteti ose një territor më i gjerë: Izgarasi, Mbrezhani, Frashëri, Postenasi, Delvinasi, Përmetasi etj. Sipas gjuhëtarit Ç. Bidollari patronimet e këtij tipi në terminologjinë e fushës quhen patronizime toponimesh, por nuk përbëjnë për një rreth atë përqindje në të dhënat e J. Shpuzës (Shpuza 1998: 74): Vaso Vangjel Dama, Shahin Kaso Frashëri, Ilo Mikle Qafëzezi, Dhimitër Jani Gjika, Kacanikli Mehmet Pasha, Anastas Kostandin Frashëri, Mihal Plumbi Përmetasi, Kostandinin Hanxhopollit Izgarasi, Harallamb Pulëshitësi Delvinasi, Janço Kosta Ogrenasi, Joan Vretua Postenanasi, Thoma Sotir Mbrezhani, Zejnel Qamil Frashëri, Mina Pano Frashëri etj. 
Në këtë periudhë gjallojnë dy tipa emrash familjeje, emri i dytë vetjak ose vendi i origjinës "Identifikimi i shqiptarëve bëhet nëpërmjet një emri vetjak që mund të jetë i babait ose i gjyshit, ndërsa jashtë vendlindjes edhe emri i fshatit për të treguar prejardhjen" (Franz 1922:4).

Në fillim të procesit të islamizimit zënë e shfaqen si emra të parë vetjak, emra të fesë islame dhe më vonë si patronime emrat e parë myslimanë siç shkruan M.Tërnava: “...në vend të patronimeve të krishtera për ta shpejtuar procesin e islamizimit dhe për t'i fiksuar rezultatet e këtij procesi në dokumente" (Tërnava 1978:591).

Dukuri të rralla fillojnë të duken edhe toponime në rol patronimi që ende nuk kanë marrë trajtën që kanë sot (emërorja e shquar), por dalin edhe në trajtën e gjinores, ose të shoqëruar edhe parafjala nga: Vasili $i$ Vangjelit Delvinasi,Mehmet Naibi i Përmetit, Murat Osman beu nga Kurtesi.

Pas shekullit XV në periudhën e fillimit të Rilindjes përmenden në dokumente me emër e emër familje, por ndihet edhe e pavetëmjaftueshme kjo formulë, e cila kishte traditë nga principatat e Arbrit. Shtohen në këtë formulë edhe disa karakterizime përshkruese: Thano Liçi i lagjes Bregas së Buhalit, Konstandin Ekonom Çelehuri-mirëbërës botimesh, Zoto Pano Duro - mirëbërës, ngriti shkolla, Nasibiu, ose Tahir Dede - studiues në Iran etj. Në periudhën e mëvonshme ndajshtimet mënjanohen në rrjedhë të shekujve.

Shfaqet në Rilindje prirja si emër familje, origjina, pra sistemi nuk është stabilizuar hasen të gjitha mundësitë e identifikimit që nga ai i ploti edhe me elemente shtesë të tipit përshkrues me tituj e ofiqe para emrit ose pas tij.: Kurt Ahmeti, Dalip Përmeti, Kristo Kanua, Ali Hani, Mehmet Këlcyra, Zoto Loli, Ilia Kristo, Refat Frashëri, Sali Bej, Jani Papa, Zafir Joanidhi, Apostol Arsaqi,Teki Selenica, Josif Surropulli,Çulli Përmeti, Kuli Kasapi, Xhoxhi Xhoga, Hajerdin Hoxha, Lufti Topojani, Hysen Trebeshina, Qirjaq Trepozishti, Lami Buhali, Barjam Borocka, Llukan Peshtani, Ali Tremishti, Mina Trepozishti, Dhimitër Kacimbra, Koço Tasi, Leonidha Frashëri, Stavro Vinjau, Jahja Efendi, Nesim Përmeti.

Më lart kemi shkruar se trashëgohen dukuri të rralla e fillojnë të duken edhe toponime në rol patronimi që ende nuk kanë marrë trajtën që kanë sot (emërorja e shquar), por dalin edhe në trajtën e gjinores: Baba Kamberi i Sukës ose titujt dhe gradat e marra në administratë u përkasin nëpunësve të ndryshëm, të cilat gjejnë në fillim bashkëngjitur pas emrave e duke u formësuar me tri gjymtyrë: Xhelal Bej Këlcyra, Islam Bej Këlcyra, Llukan Hotova Papavrami, Stefan Theodor Pellazgu etj. Emërtimet e profesioneve janë ende si në Mesjetë për shkak të zhvillimit të vendit, u prapavihen emrave të parë: Cac Tavanxhiu, Kovi Dhoga, Paskal Trëndafili, Olga Plumbi, Sotir Ura (ndërtuesi i urës së Dragotit), Stavri Opingari, Vasillaq Spiceri, Arif Tamburi, Xhevdet Kofina etj. 
Duke u përdorur edhe për pasardhësit e tyre janë bërë patronime që shënojnë profesione. Disa shërbejnë edhe si patronime dëshmi e kohës, e zhvillimit e marrëdhënieve të vendit: Janaq Dollarja etj.

Këto variante $u$ zhvilluan më tej, gati me zhvillimet e patronimisë europiane, dhe politikën gjuhësore tek vendimi i Komisisë Letrare, i cili fiton vlerën e vërtetë shekullore në pikën $2 \mathrm{ku}$ është përcaktuar si lloji më masiv i emrave të familjes të shqiptarëve duke rekomanduar si gjedhe për formim të emrave të familjes dhe shkrimin e tyre për ato familje që s'i kanë ende: "Atyne që nuk kanë emën familjeje të posaçëm, mund t'u trajtohet emni i familjes prej rrajave të syper shenjueme ose edhe tue i shtuem emnit të gjyshit shtimin prapashtesën -aj ose-ej, toskërishte-anj ose-enj, me të cilën trajtohen mbiemrta e fiseve shqiptare." Vendim shkencor qendërzues, i cili do të sillte prirjet për të dy dialektet dhe të lehtësonte më tej zbatimin e parimit historiktradicional.

Drejtshkrimi për emrat dhe emrat e familjeve ka qenë i vështirë për t'u shtjelluar gjerë për shumë arsye. Shumica e këtyre formanteve janë ndajshtesa të shqipes, por nuk mungojnë edhe ndajshtesa të huaja. Ndër parashtesat e shqipes që hasen në emrat e familjeve të fshatrave në fjalë janë: $-a j$, $-a c ̧ i$, -al, (i), -an(i), -ar(i), -çe, -ko, -uc(i), -ul(i), -osh(i), -ush(i), kurse të huaja janë prapashtesat greke: adhi,ella,opulli, kurse turke -llari, -çi, -xhi dhe romano -ino, shkruan ndër tjerat prof. R. Memushaj kur analizon formimin e patronimeve të Himarës (Memushaj, 2004:304). Disa nga këto formate i gjejmë të pasqyruara edhe në antroponimet dhe patronimet e Përmetit si e folme e Toskërishtes Veriore: Popolak, Kolaq Çapoku, Qerok, Zemaj, Koloç, Kuruc, Uzumaj, Korrollarë, Humbollarë, Voglushi, Oshafexhiu/inj, Zhulati, Zihallari, Xhillari etj.

Arsye tjetër që e vështirëson më tej shkrimin e saktë është e folura dialektore e krahinës. Nga gjuhëtarë të tjerë është vlerësuar si një dukuri tjetër tipike për toskërishten prapavendosja e pjesëzës pasthirrmore apo ndajshtesës $-o$, tek emrat e familjes që është shumë e përhapur edhe në emrat e përveçëm si: Petro, Marko... Mungon kjo dukuri në gegërishte. Prapavendosja e ndajshtesës është një dukuri relativisht e vjetër e toskërishtes, pra kemi të bëjmë një dukuri të ngulitur në këto treva shekuj më parë (Memushaj 2004:313).

Prapashtesa $-a j$ si prirje e re, formim pas vendimeve të Komisisë së Shkodrës nuk është aq prodhuese sa në pjesën tjetër të Labërisë. Mund të jetë vëzhgim i domosdoshëm shembujt e sjellë nga gjuhëtari R. Memushaj: familja ardhëse Lekaj, merrte prapashtesën -aj për të dalluar nga vendasit me të njëjtin emër familje dhe shkruhet me -aj. Ky vëzhgim është një mënyrë për të përcaktuar moshën e kësaj prapashtese tek emrat e familjeve dhe vendimet e drejta të gjuhëtarëve të Komisisë së Shkodrës një shekull më parë. 
Mbledhja e materialit u shtri në periudhën 1994-2000. Nga krahasimi, vërejtën në hollësi, ndoshta mund të ishte në pasaporta për të punuar jashtë dukuria e përmendur nga gjuhëtari, i cili emërton riinterpretim të patronimeve: "Kohët e fundit në Himarë sidomos në fshatrat greqishtfolëse të saj nën ndikimin e faktorëve ekonomikë e politikë po vërehet prirja për rintepretimin e patronimeve duke synuar modernizimin dhe në disa raste tëhuajzëzimin e tyre. P.sh.: në vend të partonimit tradicional Nerënxi, në regjistrin e zgjedhjeve: Neranxhi, Nerexini, Neraxi... Mila dhe Milios, Çakalli>Çakali etj. Disa paronima u është ndërruar forma duke përfunduar greke si: Haxhanis, Duonisis Tiandafillu" (Memushaj 2004:313).

Për Toskërishten Veriore si më afër të folmeve të tjera dhe mjaft të formuara mëshon dhe është më afër argumentit dhe pohimit që prof. Ferit Duka kur shqyrton dokumentet të Mesjetës për antroponiminë e Dropullit ka konstatuar disa tipare:

Së pari mbizotërimi i dukshëm i emrave të hapësirës shqiptare si: Mara, Kolë .. që hasen rëndom si emra ose si mbiemra, emra familjesh.

Së dyti, prania e variantit shqiptar i antroponimisë ortodokse në pjesën tjetër të emërtesës së popullsisë, të cilat paraqiten të ngjashme me ato të partonimisë shqiptaro- katolike të Shqipërisë Qendrore dhe Veriore.

Asgjëkundi nëpër faqet e defterit që po shqyrtojmë nuk shihen gjurmë të pranisë së ndikimit të antroponimisë greke karakteristikë dalluese e së cilës është fakti se mbarojnë përgjithësisht me "s" Panajotis" (Duka 2009:297).

Foneticinët duke folur për drejtshqiptimi apo për parimin historiktradicional kanë lënë të hapur dhe pa trajtuar me rregulla përcaktuese mënyrën e shqiptimit dhe shkrimit të emrave të familjeve kristalizuar më tej mënyrën e shqiptimit dhe shkrimit për dokumentacionin e domosdoshëm për çdo familje.

Pra, gjatë shekujve evolucioni i patronimeve ka ardhur duke u plotësuar, pavarësisht politikave gjuhësore. Erdhi duke u plotësuar me tipa të ndryshëm dominuesish deri sa në gjysmën e parë të shekullit të 17-të, siç nënvizon gjuhëtari Ç. Bidollari, ravijëzohet pamje e plotë me gjithë tipat që vijnë duke u stabilizuar pandërprerë. Po ky autor thekson se ka një lëvizje përbrenda sistemit, me zhvendosje raportesh, derisa sistemi mbyllet me krijimin e administratës së parë të shtetit shqiptar dhe sidomos me regjistrimin e parë të popullsisë në shtetin e ri shqiptar (1923), regjistrim që përsëritet gati çdo 10 vjet deri në vitin 1945 .

Është shkruar se duke kaluar në gojën e dhjetëra e dhjetëra brezave emrat vetjakë dhe emrat e familjeve doemos që pësojnë ndryshime tingullore nën veprimin e rregullave fonetike të gjuhës së cilës i përkasin dhe faktorëve jashtëgjuhësorë. Emrat me moshë tepër të vjetër bartin me vete pasojat e 
rregullave fonetike që kanë vepruar mbi ta në epoka të ndryshme të jetës së tyre. Kështu që studimi i ndryshimeve tingullore bën të mundur të zbulohen rregullat që i kanë shkaktuar dhe bëhet një kronologjizim i këtyre rregullave, i cili nga ana e vet merr vlerë në përcaktimin e moshës së këtyre njësive (Bidollari 2010:37).

Shqiptimi luhatet, për pasojë dhe shkrimi, megjithëse i gjejmë të shkruar në dokumente të vjetra siç ka shkruar gjuhëtari R. Memushaj për një grup të veçantë emrat e familjeve të formuar nga emra personash historikë të botës iliro-arbëreshe. Këtu hyjnë emrat: Leka, Piro, Qezar dhe Komnen nga të cilët këtë dy të fundit dalin vetëm në regjistrin turk të vitit 1583, gjë që flet për vijimësi të pandërprerë në gojën e banorëve të krahinës. Ndonëse të paktë në numër këta emra familjesh marrin një rëndësi të veçantë për të gjykuar për karakterin etnik të banorëve të këtyre fshatrave. Një vend të veçantë zënë edhe emrat e tjerë të vjetër, si: Lika, Deda, Marta, Zoto, Premti, Pali, të cilët vijnë nga botë e ilire-pagane dhe kristiane e hershme. Shumica e këtyre emrave jetojnë si antroponime e patronime edhe sot në krahinën e Himarës dhe në të gjitha nënzonat e dy bashkive Këlcyrë dhe Përmet (Bidollari 2010:299).

Ka gjuhëtarë që si kriter tjetër marrin për origjinën dhe vjetërsinë e antroponimeve duke kundruar si patronime të thjeshta pa $u$ formësuar me ndonjë ndajshtesë, por duke u paraqitur në trajtën e tyre përfaqësuese të rasës emërore njëjës.

Është përcaktim i gjetur nga gjuhëtarët që kanë hulumtuar në këtë fushë. Edhe në kërkimet tona na bie në sy mbizotërimi i gjedhes më të përgjithshme të formësimit të antroponimit gjatë procesit të patronizimit, trajta e emërores.

Grupi i emrave të familjes me formantet $-u,-a,-o \ldots$ ndihen si "trajta njëjësi të shquara"dhe në këtë mënyrë shkojnë së bashku me ato me formantin - $i$ me rregullën e shquarjes së emrave, pra, u nënshtrohet një rregulle shquarje "dialektore", prirje gjuhësore për të gjitha krahinat. Kemi të bëjmë me një dukuri dialektore që ka vepruar tek këta emra të familjes edhe pas veprimeve disa dukurive të ndryshme fonetike, pas shkurtimit të tyre, duke përjashtuar trajtën e plotë të emrit: $\operatorname{Muça(T),Muka(L),Kola(O),Sula(ZH),Pipa(P),}$ Alia(M), Salia(S), Popa(Ç), Hysa(R), Zhaka(B), Bulka(L), Naska(B), Hila(S), Ceka(M), Dafa(M), Cama(M), Ceka(M);

Përdoren dhe shkruhen drejt në trajtën grupi i patronimeve me $-u$ : Hysniu(O), Kuçuku(K), Saliu(G), Turabiu(P), Gaziu, Meshahu(B), Sadiku(SH),

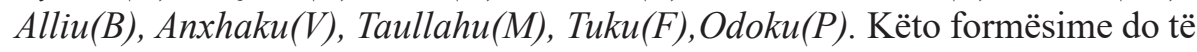
rimerren më hollësisht. 


\section{Karakteri marrëveshjesor krahinor për zgjedhjen e kompleksit gjuhësor, emër familje në Toskërishten Veriore e më gjerë}

Funksionimin evolues identifikues e hulumtuam edhe në rrethin e Përmetit, dukuri e përafërt me të gjithë shqiptarët. Rrethi i Përmetit apo dy bashkitë që janë sot Përmeti dhe Këlcyra janë pjesë e Toskërishtes Veriore. Pyetjet e drejtuara për trashëgimin e emrit të familjes në 100 fshatra të rrethit apo të dy bashkive të sotme rezultonin se trashëgohej nga gjyshi në $90 \%$ të fshatrave. Të gjithë i përgjigjeshin pyetjes për problemet që mbarte me vete emri i familjes se si duhet shkruar ky emër familje në tërësi. Zakonisht është ndalur vetëm tek fillimi më shkronjë të madhe. Ky kujdes nga shkruesit është realizuar mirë, por paraqet probleme me dokumentacionin që zotëron individi në kohë të ndryshme. Para 100 vjetësh në shekullin e kaluar megjithëse ishin vite lufte Komisia Letrare e Shkodrës u erdhi në ndihmë për të zvogëluar shqetësimet e shkrimet të emrave të familjes.

Është shkruar nga disa hulumtues të onomastikës se përdoret termi i saktë emër familje dhe është bërë disa vjet para botimit të "Les noms de personnesorigine et evolution" të autorit frëng A. Dauzat në vitin 1925 dhe shumë vjet para botimit të veprës tjetër të njëjtit autor që trajton në mënyrë të posaçme e të gjithanshme këtë tematikë: "Lesnoms de famille de France", Paris 1945. Ky autor referencohet dhe ka qenë pikërisht ai që ka dhënë kategoritë e emrave të familjes sipas prejardhjes dhe nënndarje të tjera.

Nga shqyrtim i patronimeve prej antroponimie të qindëshesh së parë do të dilnim në këtë përfundim, siç shkruan gjuhëtari Ç. Bidollari vetëm tre nga 58 patronime janë formësuar me - $\boldsymbol{a j}$, që tashmë është pranuar si ndajshtesë e specializuar për formim patronimesh. Kështu e karakterizojnë këtë ndajshtesë (prapashtesë) edhe A. Xhuvani - E. Çabej në studimin e tyre për prapashtesat e gjuhës shqipe duke ia përcaktuar funksionet në: 1. formim patronimikash, domethënë emra fisesh a çetash (Gjinaj...Gjin) dhe 2. formim emra visesh a krahinash të Jugut a Veriut të dalë nga patronimikat, Çorraj (Xhuvani 1960: 196-197).

Kemi hulumtuar për etnonimet se 98 lagje që mbarojnë me -aj, kemi një shtrirje të kësaj prapashtese tek $30 \%$ e cila ka prirje të gjerë për t'u shtrirë dhe tek emrat e familjeve me $10 \%$.

Midis trajtave të shkurtra të patronomizuara tashmë dallohen dy tipa:

1. Emra me trajta të shkurtuara që si të tillë kanë funksionuar edhe në vend të trajtave të plota siç shkruan gjuhëtari Ç. Bidollari: Nikë nga Nikoll (Bidollari 2010:37.)... plus një prapashtesë. Niçka(M), Lamçe(T), Aliçka(F), Malushi(ZH), Palosh(V), Pelushi(P), Bakushi(B), Tanuçi(T). 
2. Kategoria e dytë e emrave të këtij tipi ka funksionuar në rolin e trajtave të shkurtuara pastaj janë shndërruar në patronime: $\operatorname{Kaso}(V), \operatorname{Fejzo}(S)$, Aliko(ZH), Hodo(R), Lato(R), Sheme(R), Kule(P), Xhako(B), Bedo(B), Goni $(P G)$, Sula $(K)$, Tice(T), Ceno(K),

Duro(V), Kaso(V), Hodo(R), Arka(R), Kola(O), etj.

Formësohen $-a$, ndihen si "trajta njësi të shquara" dhe në këtë pikëpamje shkojnë së bashku me ato me $-i$ me "rregullën e shquarjes", ndonëse rregulla gramatikore e ndajshtesës i nënshtrohet një rregulle "shquarjeje dialektore" karakterit marrëveshjesor. Më tepër mëshohet në këtë rast me një prirje VeriJug duke iu referuar: Popa(Ç), Nikolla(Ç), Çoka(M), Xhavara(M), Ndina(M), Gjikokdhima(M), Naska(A), Çela(M), Teka(M), Gjika(M Gjoka(M), Dafa(M), Ceka(M), Muka(L), Muka(L), Vaka(L), Hila(S), Xhoga(Z), Laska(G), Lahja(F), Canka(M), Zhaka(K), Kita(K), Mara(D), Hysa(R), Salia(S), Pllaka(O), Kristulla, Bulka(L), Popa(Ç), Ilia(K) etj.

Pra, prirja është ndërtuar ai rregull i përgjithshëm që përcakton formimin e patronimeve që në përgjithësi përbëhet nga një emër mysliman ose i krishterë mashkulli, në "trajtë të shquar me nyje" (Boissin 1965:177), formësim me ndajshtesë.

Është plotësisht i drejtë theksimi që shumë nga këto trajta janë shndërruar në variante të "mëvetësishme", term i gjetur me shumë kujdes nga gjuhëtari Gj. Shkurtaj, pra meritojnë të shqyrtohen edhe në emër vetjakë zyrtarë si emra dokumentesh pasaporte, pra ato nuk janë më shkurtime a zbunime, por janë emra familjesh të ndërruar me marrëveshje, zgjedhje kompleksit tingullor brenda familjeve të mëdha, fisesh të gjera e në shkallë më të gjerë.

Vështrimi për patroniminë kërkon edhe dallimin e varianteve morfologjike, sepse lidhem me funksionin semantikisht të shquar, cilësohet nga studiuesi Ç. Bidollari dyfish të shquar, të tillë janë edhe si emra vetjakë, por në rastin kur dalin si patronime përforcimi i funksionit dallues, saktësues, shquarës shoqërohet formalisht me "nyjëzimin" e tyre formësimin me ndajshtesë. Dalin pa një formim prapashtesor kur përdoren me funksionin e thirrorit, zakonisht në përdorimin e folur mbizotërojnë trajtat e formësuara me ndajshtesë: $\operatorname{Tralo}(M), \operatorname{Memo}(L), \operatorname{Kano}(L), \operatorname{Hodo}(O), \operatorname{Rrapo}(Z), \operatorname{Proko}(S)$, Petro(K), Jaho(Ç), Spiro(L), Kristo(L), Duro(M) etj.

Me prapashtesën tjetër turke -llari, -leri kanë shënjuar vëllazëri a fise janë formuar patronime të shumta nga tema emrash vetjakë origjinash të ndryshme me mbizotërim të emrave islamikë: Alikollari... ndonëse nuk janë të paktë as patronimet me bazë emrash të krishterë: Stefanllari (Bidollari 2010:61), Kanellari(M), Selimllari(B), Dakollari(T), Alikollari(T), Thomollari(K), Hankollari(T),... Lamllari(ZH) (Formësohen me ndajshtesën -llari >118). 
Prania mjaft e gjerë e antroponimeve, fondi i emrave islamikë është i motivuar me kohën kur fillojnë të formohen patronimet edhe te përmetarët. Përkon merrjedhën e procesit të sundimit Osman dhe islamizimin në masë të shqiptarëve, që solli me vete edhe një fond të konsiderueshëm emrash familjesh të një natyre të panjohur më parë, në një masë të caktuar dhe të vështirë për të shqiptuar dhe të gjatë tre-katër rrokësh: Xhavara $(M)$, $\operatorname{Arshimi}(R), \operatorname{Ibrahimi}(D)$, Kamberi(O), Naumi(B), Ismaili(P), Sadiku(F), Rustemi(T), ... Odoku(P), Dyrmishi(B), Anxhaku(V), Bramati(V), Mehmeti(R), Barjami(R).

Emra familjesh që formësohen me ndajshtesën $-u$ : (Formësohen me ndajshtesën $-\boldsymbol{u}>43$ )

Toslluku(M), Kuçuku(K), Hysniu(O), Aliu(K), Sadiku(F), Haxhiu(Ç), Buxhuku(O), ... Tanku, Xherahu(P)

Formësimi me ndajshtesën $-i$ shtrihet tek shumë emra familjesh: (Formësohen me ndajshtesën $-\boldsymbol{i}>\mathbf{1 7 8}$ )

Qirici(M), Demiri(L), Jarazi(M), Stefani(A), Vangjeli(A), Paskali(A), Mihali(A), Sotiri(A), Simoni(A), Tafani(L), Këlliçi(L), Agushi(L), Rexhepi(B), Seferi(B), Ferati(B), Stefani(B), Miti(B), Ciçi(B), Poçi(B), Thanasi(T), Fani(T), Ismaili(P), Ibrahimi(B), Sulejmani(B), Tanuçi(B), Peçi(B),..Bektashi(P) (Formësohen me ndajshtesën $-\boldsymbol{a}>\mathbf{9 5}$ )

Pajtohemi me mendimin e shprehur se grupi i patronimeve me $-\mathrm{u}$ : Toslluku(M), Kuçuku(K), Hysniu(O), Aliu(K), Sadiku(F), Haxhiu(Ç),

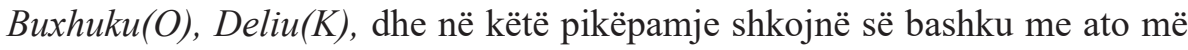
$-i$ : Qirici(M), Demiri(L), Jarazi(M), Stefani(A), Vangjeli(A), Paskali(A), Mihali(A), Sotiri(A), Simoni(A), Halili(G), Vasili(G), Toti(S), Iljazi(O) Zahari(M), Dhimuli, (M), Ndoni(M), Çuli(M), Peçi(M), Kaçi(M), etj.

Grafiku i mëposhtëm pasqyron të plotë formësimet me ndajshtesa tek emrat e familjeve. 


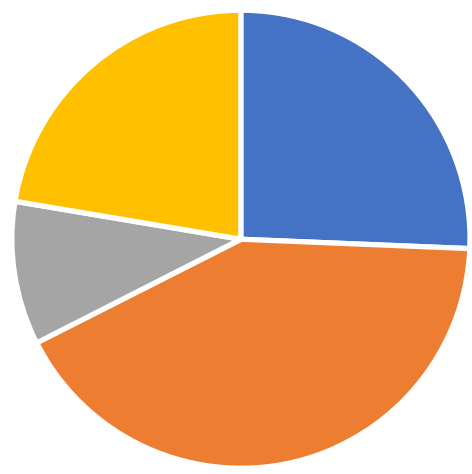

$$
\begin{aligned}
& \text { - Emra familjesh të formësuara me ndajshtesën -a } \\
& \text { - Emra familjesh të formësuara me ndajshtesën -i } \\
& \text { - Emra familjesh të formësuara me ndajshtesën -u } \\
& \text { - Emra familjesh të formësuara me ndajshtesën - Ilari }
\end{aligned}
$$

\section{Renditja e prirjeve tek emrat e familjeve si proces evoluimi}

Nga paraqitja e mësipërme dallojnë qartë se qëndron vërejtja që formulon H.Boissin në kumtesën e vet: "Ka pak emra familjesh të formuar me anë emrash të parë si abstraktë të tipit "Shkëlqimi". Është e shpjegueshme, sepse emra të tillë nuk kanë kaluar në patronime, për ne është befasuese që del në Regjistrin e kadastrës dhe të Koncesioneve për rrethin e Shkodrës 14161417", patronimi Kujtimi, Pjetër Kujtimi (Bidollari 2010:57) i cili nuk haset as sot në materialin e mbledhur në rrethin e Përmetit.

Rregullat e thjeshta dhe mjaft të domosdoshme nga Komisia Letrare e Shkodrës në shekullin e kaluar çuan në prirjen Jug-Veri për shtrirjen nga katër prapashtesa dy për Jugun dhe dy për Veriun në shtrirjen e emrave të familjes që mbarojnë me $-a j$, ndoshta ishte parashikuar si prapashtesë për Veriun. Një nga arsyet kryesore janë edhe lëvizjet brenda sistemit.

Më 1 shtator 1948 kur miratohet ligji për emrat vetjakë, i cili botohet në "Kodifikimi i përgjithshëm i Legjislacionit në fuqi të Republikës popullore të Shqipërisë. Aneks 1959-60, Tiranë. Botim i kryeministrisë,1961.

Sot ky sistem me këtë larmi tipash e trajtash dhe arrin të bëjë identifikimin e shtetasve me formulën dygjymtyrëshe dhe në rrethana tepër formale, për ta bërë më të saktë fut në punë edhe formulën trigjymtyrëshe. Gjithsesi ky sistem që kemi sot rezultat i një evolucioni të gjatë është në pajtim të plotë me sistemin europian të identifikimit, duke i ngërthyer të gjithë tipat e patronimeve që i 
gjejmë tek A. Dauzat "Lesnomsdesfamille de France", Paris,1949, zbatuar për herë të parë për shqipen nga studuiesi tjetër francez Henri Boissin.

Hulumtuam prirjen e zgjedhjes së kompleksit tingullor. Në të tri bashki tëpër gjedhen e shfaqur në media nëse ka shtrihet edhe tek patronimia. Megjithëse emrat vetjakë të formuar me prapashtesën -im kanë frekuencë të lartë përdorimi pas politikës gjuhësore të viteve 70-të: Agimi (64), Kujtim (43), Pajtim (34), Bashkim (31), Shkëlqim (27) etj., nuk kanë kaluar në emra familjesh. Ndoshta duhet kohë që të kthehen në emra familje.

Kjo prirje e gjerë, e bukur s'përmendet nga anketuesit studentë, mënjanohet nga anketuesit, duke mos e përmendur.

Ndryshimet e mësipërme argumentohen edhe me faktorë të tjerë që pasqyron anketa e zhvilluar me studentë të vitit të parë gjuhë-letërsi, me studentë vitit të parë, master gjuhë-letërsi në maj 2016, 2017.

Pra, për të argumentuar më tej politikën gjuhësore për antroponiminë dhe patroniminë zgjeruan shtrirjen, gjeografike në shumë bashki të vendit. Analizuam për dy vite emrat e studentëve të cilët vijnë nga bashki që shtrihen edhe në Veri të vendit. Antroponiminë dhe patroniminë e studentëve të vitit të parë të Fakultetit të Shkencave Humane, Universiteti "Ismail Qemali", e hulumtuam për të parë se cili ishte emri më i përdorur me frekuencë më të lartë për vitet 2015-2017. Si ka vijuar moda e zgjedhjes, karakteri marrëveshjesor nga kuvendet familjare edhe në pragun e viteve 1998-2000, për kompleksin tingullor? Si vijon kjo modë me dhe patroniminë e prindërve?

Emri me frekuencë më të lartë është Anxhela (17), pastaj renditen: Krisjana (5), Françeska (4), Antonela (4), Sidorela (4), Esmeralda (4), Sara (4), Klea (3), Anisa (3), Xhoana (3), Daniela (3) etj. 
Tabelë krahasuese për prirjen e emrit të familjes:

\begin{tabular}{|c|c|c|c|c|c|c|c|}
\hline \multicolumn{3}{|c|}{ Antroponimet } & \multicolumn{2}{|c|}{ Atësia } & \multicolumn{3}{|c|}{ Patronimet } \\
\hline $\begin{array}{l}\text { Order } \\
\text { count }\end{array}$ & \multicolumn{2}{|c|}{$\begin{array}{l}\text { Unfiltered word } \\
\text { Occurrence }\end{array}$} & $\begin{array}{ll}\text { Order } & \mathrm{U} \\
\text { count } & \mathrm{O}\end{array}$ & $\begin{array}{l}\text { Unfiltered word } \\
\text { Occurrences }\end{array}$ & $\begin{array}{l}\text { Order } \\
\text { count }\end{array}$ & \multicolumn{2}{|c|}{$\begin{array}{l}\text { Unfiltered word } \\
\text { Occurrence }\end{array}$} \\
\hline \multicolumn{2}{|c|}{ 1. Anxhela 17} & 4.6322 & 1. Artur 7 & 1.9126 & 1. $\mathrm{Xh}$ & eraj 6 & 1.6349 \\
\hline \multicolumn{2}{|c|}{ 2. Kristjana 5} & 1.3624 & 2. Astrit 7 & 1.9126 & 2. Но & $\mathrm{la}(\mathrm{j}) 5+3$ & 1.3624 \\
\hline \multicolumn{2}{|c|}{ 3. Françeska 4} & 1.0899 & 3. Luan 7 & 1.9126 & 3. $\mathrm{Mu}$ & aj 4 & 1.0899 \\
\hline \multicolumn{2}{|c|}{ 4. Antonela 4} & 1.0899 & 4. Petrit 6 & 1.6393 & 4. $\mathrm{Mu}$ & afa 4 & 1.0899 \\
\hline \multicolumn{2}{|c|}{ 5. Megi 4} & 1.0899 & 5.Viktor 5 & 1.3661 & 5. Sul & & 1.0899 \\
\hline \multicolumn{2}{|c|}{ 6. Sidorela 4} & 1.0899 & 6. Vladimir & 1.3661 & 6. Vei & & 1.0899 \\
\hline \multirow{2}{*}{\multicolumn{2}{|c|}{ 7. Esmeralda 4}} & 1.0899 & 7. Agim 5 & 1.3661 & 7. $\mathrm{Ha}$ & & 0.8174 \\
\hline & & 1.0899 & 8. Sokrat 4 & 1.0929 & 8. Bre & & 0.8174 \\
\hline \multicolumn{2}{|c|}{$\begin{array}{l}\text { 8. Sara } 4 \\
\text { 9. Ermelinda } 3\end{array}$} & 0.8174 & 9. Arben 4 & 1.0929 & 9. Do & & 0.8174 \\
\hline \multicolumn{2}{|c|}{ 10. Klea 3} & 0.8174 & 10. Ardian & 1.0929 & 10.M & & 0.8174 \\
\hline
\end{tabular}

Prirja e kompleksit tingullor e antroponimisë së prindërit të studentit është krejt e ndryshme nga ajo e studentit duke patur frekuencë të lartë përdorimi: Artur (7), Astrit (7), Luan (7), Petrit (6), Vladimir (5), Agim (5), të cilët nuk kanë pasqyrim si emër familje.

Ndërsa patronimet pasqyrojnë shumë pak politikën gjuhësore pasi ndryshohen shumë ngadalë duke dalë me frekuencë përdorimi më të madh: Hoxha (5)+ Hoxhaj (3), Xhaferaj(6), Muçaj(4) etj., të cilët janë patronime të trashëguara në shekuj dhe të fosilizuar nga politika gjuhësore islamike e pesë shekujve më parë, ndoshta edhe nga telenovelat e disa televizioneve me denduri shfaqje deri tre në ditë.

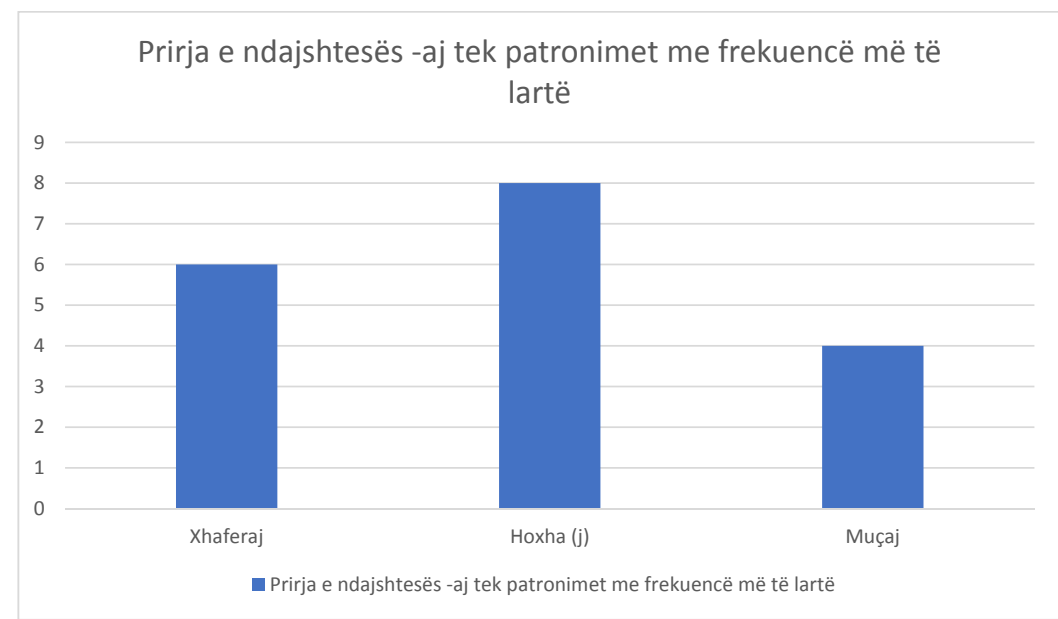


Konsolidohet prirja e Komisisë Letrare të Shkodrës të formësimit të emrit të familjes me ndajshtesën $-a j$ e cila është renditur tek patronimet me frekuencë më të lartë siç paraqitet në grafik dhe si prirje Veri-Jug.

Pas rënies së diktaturës, pas viteve 1990-të kjo politikë gjuhësore megjithë botimin e studimeve për emrat, emrat familjarë nuk u zbatua për shumë faktorë të tjerë të radhitur edhe nga anketuesit si: liritë e zgjedhjes së kompleksit tingullor, gjedha e emrave të perëndimit, moda emrit të emigrimit etj. Emri i familjes, kompleksi tingullor ndryshon shpejt për shkak të politikës gjuhësore ku shqiptari emigron në Europë, apo diku tjetër.

\section{Bibliografi}

Adhami, S. (2001). Përmeti dhe përmetarët në faqet e historisë.

Bidollari, Ç. (2010). Hulumtime onomastike. Tiranë.

Boissin, H. (1965). Sprovë e përkohshme për një klasifikim të emrave të përveçëm në shqipe, në "Konferenca e parë e Studimeve Albanologjike". Tiranë.

Duka, F. (2009). Shekujt osmanë në hapësirën shqiptare. Tiranë.

Franz, S. (1922). Ergebenisse der Vollzahlung in Albaniien in dem vonoster-ungar.

Kostallari, A. (2017). Vëll.4. Tiranë.

Memushaj, R. (2004). Patronimia e Himarës, në "Himara në shekuj”. Tiranë.

Robins, R. (2007). Historia e gjuhësisë. Tiranë.

Shpuza, J. (1998). Vëzhgime për emrat familjarë të shqiptarëve. Shkodër.

Tërnava, M. (1978). Onomastika e Kosovës. Tiranë.

Xhuvani,A. (1960). Prapashtesat e gjuhësshqipe. Tiranë.

Nexhip Mërkuri

\section{Albanian Patronymics in Balkans and European Evolution}

\section{Summary}

The author reflects the evolution of patronymic properties during centuries. The developments and respective patronymic expectations are given after the collected material in archives found in numerous regions from several expeditions.

It is examined as a Balkan linguistic phenomenon for Illyria, Arbëria, Albanian language. Evolution of patronyms has come to fruition, despite language policies. The Middle Ages reveal a breakdown of the system and family names by the Ottoman occupation of the country.

The Ottoman conqueror, along with religion, brought anthroponyms, Islamic partonomy as part of his linguistic policy. This language policy began to substitute the Arbereshe names, the Albanian names who were only Christian before.

During the Middle Ages, the identification of Albanians was done through an own name, a patronym coming from his father or grandfather, or the name of the vil- 
lage or the province, to show their origin. Later numerous leader names are commonly used, until the declaration of Independence.

In the period of Independence, it's observed a tendency to identify the patronym with the birthplace, the village or city, or other phenomena that have been noticed in Balkan and European languages. The focus is on the research of patronymic evolution in the last 100 years.

It is assessed the inherited situation from Turkish ruling, and are provided cultivated tendencies by the Literary Commission of Shkodra. The cooperation between the linguists of experienced European universities in Shkodra (1 September 1916) lead to the conclusion that Albanians, generally, have family names derived from some duty level, or from the village or the city from which their families came from, or their mastery, or the unique names of their male ancestor.

The exact term family name it's proved to be most preferred from other researchers and scholars, as development, evolution - compared to the publication of French author A. Dauzo on the theme: "Les noms de famille de France", Paris 1945. Author's research, are part of extensive study in the onomastic field.

Keywords: patronymic properties, Balkan linguistic, Illyria, middle-ages, evolution of patronyms, cultivated tendence, Literary Commission of Shkodra, provincial pronunciation. 